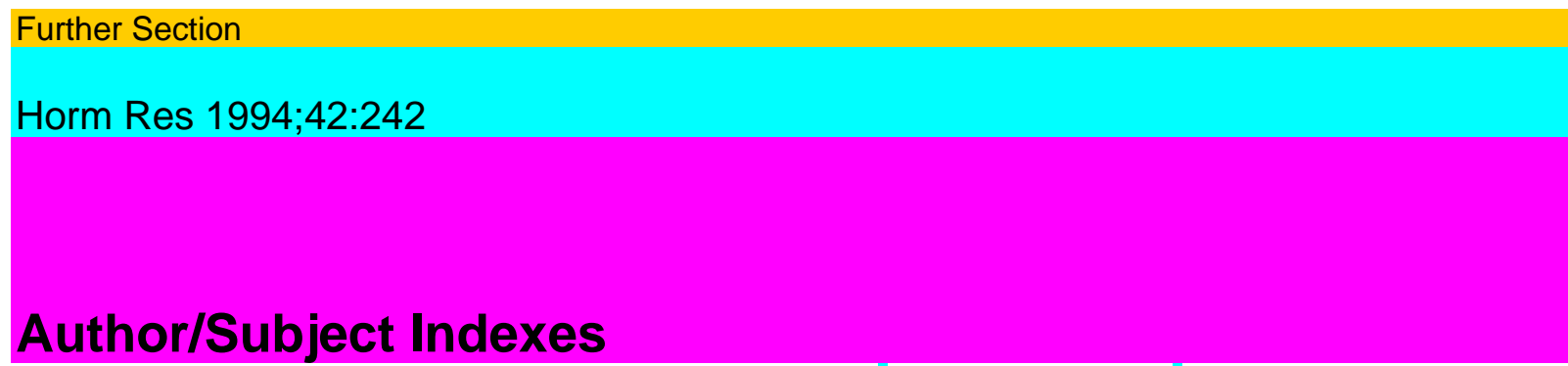

Abe,H. 182 Argente,J. 189 Barker, D.J.P. 223 Baxter, R.C. 140 Bridges, N.A. 231 Brook, C.G.D. 231 Chihara,K. 182 Christiansen, J.S. 235 Christoffersen, C. 152 Clemmons, D.R. 145 DeMeyts, P. 152 Dinerstein, H. 133 Edery,M. 133

Ekström, T.J. 176 Esposito, N. 133 Evain-Brion, D. 207 Finidori, J. 133 Goujon, L. 133

Gronowski, A.M. 170 Grønskov, K. 152 Hay,W.W.,Jr. 215 Hondo, M.M. 152 Jørgensen, J.O.L. 235 Juul,A. 235 Kaji,H. 182 Kelly, P.A. 133

Ketelslegers, J.-M. 145 Klinger,B. 198 Laron,Z. 198 Latus, L.-J. 152 Lemozy, S. 145 Lowy,C. 203 Møller,J. 235 Müller,J. 235 Okimura,Y. 182 Perez Jurado, L.A. 189 Postel-Vinay, M.C. 133 Rosenfeld, R.G 129 Rotwein,P. 170

Shakutsui,S. 182 Shymko, R.M. 152 Skakkebæk, N.E. 235 Sotiropoulos, A. 133 Thissen, J.-P. 145 Thomas, M.J. 170 Uchiyama, T. 182 Underwood, L.E. 145 Ursø,B. 152 Vahl,N. 235 Wallach,B. 152 Wolthers, T. 235 Yakushiji, F. 152

Achondroplasia 231 Acid-labile subunit 140 Amino acids 215 Birth weight 223 Carbohydrates 215 c-fos 170

Coronary heart disease 223 Diabetes 223 Fatty acids 215 Feedback regulation 182 Fetal growth 207, 223

- regulation 203

undernutrition 223 Fetus 207,215

Gene regulation 170 Glucose 215

- $\quad$ homeostasis 140

Growth hormone 129,182,189,235

- binding protein 129

- deficiency 189,235

- -, diagnosis 145

- gene deletion 189

- insensitivity 129, 198

- rapid nuclear actions 170

- receptor 129,133,198

- - deficiency 129

- releasing factor mRNA 182

- resistance 198 Hypertension 223 Hypochondroplasia 231 Insulin-like activity 140 growth factor(s) 140, 145, 170, 182

- - binding proteins 140,145

- - bioavailability 140

- - receptors 152

- - treatment 198 Insulin receptors 152 Intrauterine growth, regulation 203 JAK2kinase 133

Laron syndrome 129,198

Lipids 215 


\section{MAPkinase 133}

Maternal diabetes 203

Metabolic signaling 152

Mitogenic signaling 152

Nutrients 215

Parental imprinting, insulin-like growth

factor 2 (IGF2) gene 176 Passive immunization 182 Pituitary transcription factor Pit-1 189 - gene deletion 189 Placenta 207,215 Placental nutrient exchange 203 Protein restriction 145 Receptor dimerization 152 Recombinant human growth hormone 231 Signal transduction 133 Skeletal dysplasia 231 Ternary complex 140 Tyrosine kinase(s) 133,152 